\title{
Breathing Space
}





\section{Breathing Space}

How Allergies Shape Our Lives and Landscapes

\section{GREGG MITMAN}


Portions of material in chapters 1, 2, and 3 of this book were published in different form in the following:

"Hay Fever Holiday: Health, Leisure, and Place in Gilded-Age America," Bulletin of the History of Medicine 77 (2003): 600-635.

"Natural History and the Clinic: The Regional Ecology of Allergy in America," Studies in History and Philosophy of Biological and Biomedical Sciences 34 (2003): 491-510.

"When Pollen Became Poison: A Cultural Geography of Ragweed in America," in The Moral Authority of Nature, ed. Lorraine Daston and Fernando Vidal (Chicago: University of Chicago Press, 2004), 438-465.

"Geographies of Hope: Mining the Frontiers of Health in Denver and Beyond, 1870-1965," Osiris, 2nd ser. 19 (2004): 93-111.

Copyright (c) 2007 by Gregg Mitman.

All rights reserved. This book may not be reproduced, in whole or in part, including illustrations, in any form (beyond that copying permitted by Sections 107 and 108 of the U.S. Copyright Law and except by reviewers for the public press), without written permission from the publishers.

Designed by Mary Valencia.

Set in Stone by Keystone Typesetting, Inc. Printed in the United States of America.

Library of Congress Catalog Card No. 2006052827

ISBN: 978-0-300-11035-7 (cloth : alk. paper)

A catalogue record for this book is available from the British Library.

The paper in this book meets the guidelines for permanence and durability of the Committee on Production Guidelines for Book Longevity of the Council on Library Resources.

$\begin{array}{llllllllll}10 & 9 & 8 & 7 & 6 & 5 & 4 & 3 & 2 & 1\end{array}$ 
To my parents 
